\title{
PASTORAL FARMING IN NELSON
}

\section{G. J. Batten}

Advisory Services Division, Ministry of Agriculture and Fisheries, Nelson

\section{D. LAFFAN}

Soil Bureau, DSIR, Nelson

\section{A hstract}

Nelson is a difficult farming district with only one-third farmable, inherently poor soils, and fragmented farming areas. Dairying predominates in the wetter northern and southern parts, with sheep and cattle on the hills, and wide enterprise diversity on the eastern coastal plains. There is scope to increase production from existing pastures, but little new land development is expected apart from Golden Ray pakihi. Expansion of production will not be rapid, influenced as it is by land use competition from forestry and by individual farm physical and- 'inancial limitations.

\section{INTRODUCTION}

"Nelson is a district of scenic charm. It has an equable and sunny climate and a pattern of farming as diverse, or more so, than any other part of the Dominion. Nelson is a fruitful province. Climate and encircling mountains have made its fertile flats highly productive. Fruit, hop and tobacco growing, cropping, pastoral farming, dairying, and early cropping are highly developed and specialized. In its hinterland of difficult and marginal country the lowlands are turning to furrow and disc as marginal land comes into pasture, while the more difficult country is being extensively re-afforested to exotic timbers for industry and export."

That direct quote from the opening paper at the 1954 Conference is just as valid now. This paper updates that contribution by Messrs Merry, Adamson, and R. H. Scott. First, the basic facts about the region.

\section{HISTORY}

Nelson is one of the earliest settled farming districts. At the same time as Wellington was being settled, Nelson immigrants were carving farms from fern, manuka, and swamp near the coast; and by the 1860 s several grazing runs had been taken up in the Murchison area. However, farming in the region has 
always been difficult and gold and timber were two of the early utilized natural resources that influenced development.

\section{SOIL RESOURCES}

The Nelson region has few soil resources that are well suited for pastoral production and use. Hill and steepland soils account for $88 \%$ of the region with $65 \%$ of these soils having severe to very severe limitations to pastoral use. Soils of the flat and rolling lands with slight limitations to pastoral production and use occupy only $8 \%$ of the region.

The soils of the region have been grouped into limitation classes for pastoral use similar to those outlined by Gibbs (1963). The groupings are made for soil sets (N.Z. Soil Bureau, 1968) and are based solely on soil properties as follows:

CLASS 1: Soils of flat and rolling lands with slight soil limitations to pasforal production and use (79 000 ha, 8\%)

Class 1 includes all the soils of the lowland flood plains and terraces. Most are well drained, with the main limitation of nutrient deficiencies. In the lower rainfall areas bordering Tasman Bay summer moisture deficit is a further limitation in welldrained soils (e.g., Waimea, Ranzau, Riwaka, and Hau soils).

Soils with main limitations of drainage impediments and nutrient deficiences (e.g., Richmond and Braeburn soils) occupy only a minor proportion of floodplains.

CLASS 2: Soils of flat and rolling lands with moderate soil limitations to pastoral production and use (25000 ha, 3\%)

Class 2 includes soils with main limitations of nutrient deficiencies and seasonal moisture deficit. Representative soils are Mapua soils developed from weathered greywacke conglomerates (Moutere Gravels) on rolling land. They are imperfectly drained with low nutrient status. Topsoils are overwet in winter, but dry out excessively in summer.

Class 2 also includes soils with main limitation of low soil temperature (e.g., Tasman and Tophouse soils) and a short growing season.

CLAss 3: Soils of flat and rolling lands with severe soil limitations to pastoral production and use (16 000 ha, 2\%)

Class 3 includes soils with main limitations of subsoil pans and drainage impediments (e.g., Onahau and Denniston soils), 
those with main limitation of low soil' temperatures (Kairuru soils) and those with main limitations of frequent dryness and excessive drainage (e.g., Tahunanui soils).

Class 4: Soils of hilly and steep lands with slight to moderate soil limitations to pastoral production and use (19 000 ha, $2 \div$ )

The main limitation of these soils is nutrient deficiencies although the natural nutrient status of most is medium or high. Some representative soils include Tarakohe hill and Brooklyn hill and steepland soils. Heslington steepland soils near the eastern side of Tasman Bay have a further limitation of summer moisture deficit.

Class 5: Soils of hilly and steep lands with moderate to severe soil limitaions to pastoral production and use (202 000 ha, 20\%)

The main limitation of these soils is nutrient deficiencies and the natural nutrient status of most is low. This class includes all the hill soils formed on Moutere Gravels. Some steepland soils (e.g., Ketu and Atawhai) also have a limitation of erosion hazard. Soils near Tasman Bay have a further limitation of summer moisture deficit (Mapua, Rosedale and Wakatu hill, Ketu and Atawhai steepland soils).

Class 6: Soils of hilly and steep lands with severe to very severe soil limitations to pastoral production and use (658 000 ha. $65 \%)$

The main limitations of this class are nutrient deficiencies and severe erosion hazard. Most class 6 soils occur on the mountain lands and are unsuitable for pastoral use.

\section{PHYSICAL FACTORS JN FARMING TERMS}

Practically every known nutrient deficiency can be seen-in the field and some- still remain to be solved despite world-renowned work by Cawthron Institute.

Nelson is mountainous. Only one-third of the one million hectare region is occupied and farmable and this is scattered, broken, and isolated. The river valleys that drain the hinterland have narrow associated plains, and contour on the remainder is not easy. Thousands of hectares were originally cleared on country 
now accepted as being too difficult to farm. The now fragmented farming areas are based on a stretched roading system and small rural communities. Transport costs are high, both for outputs and for inputs. There is no physical rail access to the region and Nelson is relatively isolated from the rest of New Zealand. Overheads on processing are high consequent on small output of regionally based units.

Rainfall is affected by topography, varying from 3800 to $1000 \mathrm{~mm}$. Although the renowned sunshine and lack of wind favour horticulture crops in the northeast of the region, and together with generous rainfall encourage pasture growth in the northwest, summer droughts on the eastern side, and cold winters in the south restrict pasture production. Clovers were killed by the 1972 and 1973 droughts and Murchison farmers cannot rely on pasture growth from late May to early September.

\section{TYPES OF FARMING}

Livestock production is universal in Golden Bay where there are larger farms and adequate rainfall. Dairying predominates on the more fertile valley floors with a few sheep farms on adjacent hills. The developing pakihi is often farmed as a dairy farm ruroff with dairy-bred beef. The same pattern of dairying on the flats with sheep and cattle on the hills is found in the southern Murchison end of the region under less favourable climatic conditions.

On the Waimea side, with less reliable rainfall and good soils only in patches, farming is very diversified. Close to the coast can be found practically very type of enterprise that exists in New Zealand. Tobacco and pip fruit are two important crops in the district and these produce as much farm revenue as pastoral products from the whole region.

In addition, hops, berry fruit, and stone fruit production come from the better soils. Scattered throughout are dairy farms on smaller properties, sheep and cattle on the hills, and arable farms of varying size and intensity.

\section{THE FUTURE}

Small farm size, in both physical and income-earning terms, has been and will continue to be a major determinant of farming. The Nelson region is a delightful place in which to live and people arrive from all parts of New Zealand and the world to 
settle. Those that are born in Nelson tend to stay. They are prepared to accept restriction on income and living standards as measured in commonly accepted materialistic terms to gain the benefits of way of life as defined in allegedly esoteric terms. This desire to live in the area has tended to perpetuate small farm units and the number of holdings in Nelson has decreased at only one-tenth of the rate of the rest of New Zealand.

Two examples of farm size will illustrate. In an economic survey of a typical farming area, one-quarter of the farms had an income below that considered to be half economic. Two-thirds of the sheep flocks in Nelson have fewer than 500 total sheep and three-quarters have fewer than 1000 sheep.

\section{DAIRYING}

The dairying industry is suffering from fragmentation and low supplier numbers, and the universal swing away from the twicedaily milking chore. On the eastern side of the district the number of suppliers has declined markedly - from 725 in 1954 to 125. Small herds can be expected to continue to disappear. Herd size of those remaining in dairying is expected to continue to increase.

In Golden Bay, dairying will continue to progress. Marked expansion can come from the establishment of dairying on pakihi and, when the problems of this are solved, there will be the possibility of a considerable number of new dairy farms. However, this must be considered in the light of the future for beef.

\section{BEEP}

The profitability of beef production per se, and in relation to other livestock enterprises, will continue to be the major determinant of its future on both breeding and finishing farms. Dairybred beef animals have been important in Golden Bay, but recent low prices have forced them out of favour. While pakihi is used as dairy runoffs, beef will be the preferred enterprise if prices are reasonable, but, as mentioned above, development of a dairying system on pakihi could lead to their replacement by milking cows. Pasture growth conditions tend to favour sheep in the Waimea County, but adoption of more sophisticated beef grazing management techniques, which have enabled slaughter weights to be achieved before the drought, could have some influence on future enterprises. 


\section{SHEEP}

The future of sheep will be affected by wool and lamb prices, and stock quality and flock size are also important. Low lambing percentage reflects summer pasture production problems, but also highlights scope for improved management.

\section{Pasture Production}

There is scope for increased production from increasing carrying capacity of existing pasture, especially with increased fertilizer and subdivision. Stock number increases in the region in the 1960s are related to increased fertilizer use and there is evidence that this trend can continue. In addition, from the latest figures available, about $20 \%$ of sown grassland is not topdressed and obviously offers scope for increased production.

Improved summer growing species will be of help in the drier parts of the region. However, irrigation is likely to be too expensive for use in a pastoral farming system.

\section{Pasture Management}

Farm advisers have pinpointed improvements in animal nutrition as the major opportunity to increase farm production and profit. In a pastoral sense this usually means betrer grazing management and the elements to achieve this are slowly being understood and introduced. One big factor has been the lack of stock water, which restricts grazing management.

\section{AND DEVELOPMENT}

The 170000 ha of undeveloped occupied land is not likely to show any significant change until farmers' average age drops, farming profitability improves, and more profitable improvement of developed land has been carried out. Present costs and returns are against the development of the remaining more difficult land. In fact, further land development on a now economic farm unit might be better to forestry than to more pasture.

Even so, the motivation to develop land is largely related to the individual farmer who will develop to consolidate an economically sized unit, to expand to carry another labour unit, and to claim for tax-deductible expenses. These points are less relevant with small farms. 
FORESTRY

A major factor affecting pastoral production will be forestry growth. Timber production has been shown to be a viable alternative land use to pastoral products in the region. With good timber growing conditions, processing facilities, outlets, and relative profitability, it is anticipated that forestry will certainly replace farming on undeveloped and low productivity hill country in the Waimea and Motueka basins. This trend would reflect decisions of individual property owners, but could be affected by national or regional policy decisions such as zoning.

The scope for farm forestry is limited by farm size. The forest/ grazing system is limited for the same reason, but more especially by gorse control problems on poorer hill country. The potential for increased pastoral production on hill country in the region is directly related to farming profitability alone and in relation to forestry profitability.

\section{FARMERS}

Present and future production depends on people $\rightarrow$ mainly farmers. They are the people who have to translate the resources of soils, sun and rain, money, and information into animal products. The importance of farmers in this equation is shown by the stagnation in national livestock production in recent years. Since 1968-9, farmers have made practically no progress in turning scientific and technical information into production and profit. Nelson farmers are no different from farmers throughout the country in this regard, but we do not know all the reasons why.

We know that there are a relatively large number of small farmers with low income levels. Aspiration in usually accepted financial terms is not high, but that is not a criticism. Their borrowing ability is not high, even if they did want to borrow, so production improvement depends largely on income.

Future pastoral production progress will not be rapid in the Nelson district. The physical and man-made constraints coupled with competition from other land users will restrict total production. Individuals' progress will inevitably be built around farming profitability, and also about their way of life.

\section{REFERENCES}

Gibbs. H. S., 196.3. Soils of New Zealand and their limitations for pastoral use. N.Z. Soil Bureau Pub!. No. 308.

N.Z. Soil Bureau, 1968. General survey of the soils of the South Island, New Zealand. N.Z. Soil Bureau Bult. 27. 


\section{APPENDIX}

\section{Classification of Soils of Nelson Region for}

Pastoral Production and Use

Class 1: Soils of flat and rolling lands with slight soil limitations to pastoral production and use.

1A Limitations of nutrient deficiencies (68 $000 \mathrm{ha}$ ):

Waimea, Riwaka, Ronga, Sherry, Hokitika, Karamea, Hau, Ranzau, Motupiko, Rai, Kikiwa, Ikamatua, Ahaura, Hamama, Puramahoi, Otere, Rameka, Mahinapua soils.

18 Limitations of drainage impediments and nutrient deficiencies (It 000 ha):

Richmond, Braeburn, Karangarua soils.

Class 2: Soils of flat and rolling lands with moderate soil limitations to pastoral production and use.

2A Limitations of insufficient moisture and to a lesser extent nutrient deficiencies (16 000 ha):

Wakatu, Mapua, Wantwood soils.

2B Limitations of low soil temperature due to elevation (9000 ha) : Craigieburn, Tophouse, Katrine, Howard, Tasman soils,

Class 3: Soils of flat and rolling lands with severe soil limitations to pastoral production and use.

3B Limitations of subsoil pans and drainage impediments (11 700 ha) :

Onahau, Kotinga, Puponga, Denniston soils.

3C Limitations of excessive moisture, shrinkage ( $800 \mathrm{ha}$ ): Kini soils,

3D Limitations of low soil temperatures due to elevation (900 ha): Kairuru soils.

3E Limitations of frequent dryness and excessive drainage (2600 ha):

Tahunanui, Okari soils.

Class 4: Soils of hilly and steep lands with slight to moderate soil limitations to pastoral production and use.

Limitations of nutrients (19 000 ha) :

Hill soils - Orinoco. Brooklyn, Tarakohe.

Steepland soils - Heslington, Brooklyn.

Class 5: Soils of hilly and steep lands with moderate to severe soil limitations to pastoral production and use.

Limitations of nutrient deficiencies (202 $000 \mathrm{ha})$ :

Hill soils - Stanley, Rosedale, Spooner, Korere, Hope, Paturau, Otere, Ligar, Wakatu, Tadmor. Pikikiruna, Tutaki, Howard, Arahura, Blackball, Kawatiri.

Steepland soils - Whangamoa, Pikikiruna, Tutaki, Ketu, Atawhai. 
Class 6: Soils of hilly and steep lands with severe to very severe soil limitations to pastoral production and use.

6A Limitations of nutrient deficiences and erosion hazard (90000 ha) :

Hill soils - Kaiteriteri, Puponga, Pakawau, Denniston. Steepland soils - Pokororo. Dun.

6B Limitations of severe erosion hazard (568 000 ha): Hill soils - Onekaka, Kaniere, Matiri.

Steepland soils - Opouri, Onekaka, Kawatiri, Patriarch, Spenser, Matiri, Glenhope, Whitcombe, Hohonu, Haupiri, Lewis, Wakamarama, Haast, Kaniere, McKerrow, Pelorus, Alpine. 